\title{
Anti-hyperglycemic activity of Centella asiatica is partly mediated by carbohydrase inhibition and glucose-fiber binding
}

Ashraf UI Kabir, Mehdi Bin Samad, Ninadh Malrina D'Costa, Farjana Akhter, Arif Ahmed and JMA Hannan

\begin{abstract}
Background: Centella asiatica (C. asiatica) was previously reported to have anti-hyperglycemic effects in animal diabetic model rats. However, its activity on organ and tissue level remains unstudied. Our study aims at exploring the possible effects, C. asiatica extract and insoluble fiber has on carbohydrate absorption, insulin secretion, insulin sensitivity and glucose utilization.
\end{abstract}

Methods: For primary evaluation of anti-hyperglycemic activity, we measured Fasting Blood Glucose and performed Glucose Tolerance Test, in type 2 diabetic rats. To further study the pancreatic effect and glucose utilization, plasma insulin concentration, insulin secreted from isolated rat islets and liver glycogen were assayed. Effect on carbohydrate break down was assayed using intestinal disaccharidase enzyme, a-amylase inhibition assays and Six-Segment study of the Gl tract. Effect of $C$. asiatica on glucose absorption was studied by an in-situ, perfused, intestinal model in rats and by glucose-fiber binding assay. Gastrointestinal motility was seen by a $\mathrm{BaSO}_{4}$ milk traverse test. Additionally, a complete lipid profile assay, after a chronic study, was conducted.

Results: C. asiatica showed no significant change in insulin secretion in-vivo and in isolated rat islets. Additionally, no effect of the extract was seen on liver glycogen deposition. Retarded glucose absorption was seen in the in-situ perfused rat intestinal model at a dose. The extract was also found to inhibit action of both intestinal disaccharidase and a-amylase. This was confirmed, yet again, via the Six Segment study, where sucrose digestion was found to be inhibited throughout the length of the GI Tract. Significant glucose-fiber binding was demonstrated in the in-vitro models. During the chronic study, body mass of $C$. asiatica treated Type 2 diabetic rats returned to normal and their polydipsic and polyphagic conditions were also improved. Chronic treatment of C. asiatica also improved subject's lipid profile.

Conclusion: A combination of in-vitro, in-vivo and in-situ tests confirmed the anti-hyperglycemic activity of $C$. asiatica and its tissue level mechanism. Further study is required to fully elucidate the effect this extract or the active compounds have on the individual glucose transporters and the precise mechanism of glucose-fiber binding.

\section{Background}

In the last few decades, diabetes has established its position as one of the world's predominant endocrine disorder [1]. The number of people to be affected by this disease by the year 2000 was estimated to be 171 million, by World Health Organization [1]. Diabetes, by nature, cannot be completely cured rather it has to be kept

\footnotetext{
*Correspondence: ashraful_kabir@ymail.com

Department of Pharmacy, North South University, Dhaka, Bangladesh
}

under tight control [2]. This control might be achieved, by modifying lifestyle, medications, diet, or a combination of all of these [3]. Many of the drugs currently in use, are expensive and have adverse effects which, in tandem, makes diabetes management even more difficult [4]. Complementary and Alternative Medicines (CAM) therefore have a large room to bring about improvements in the current practices of diabetes management. CAM is rapidly growing popular throughout the world

\section{(O) BioMed Central}

(c) 2014 Kabir et al.; licensee BioMed Central Ltd. This is an open access article distributed under the terms of the Creative Commons Attribution License (http://creativecommons.org/licenses/by/2.0), which permits unrestricted use, distribution, and reproduction in any medium, provided the original work is properly cited. 
[5]. Furthermore, CAM therapy is relatively cheaper than synthetic, patented drugs in the perspective of developing countries. A large segment of the population in these countries are traditionally reliant on CAMs for managing a multitude of disorders including, diabetes [6]. However, evidences regarding efficacy of these therapies are still sparse and their mechanism of action is often unclear [7]. Centella asiatica is a widely used traditional remedy in both Africa and India. The water extract of the whole plant is used by traditional healers in Bukoba district, Tanzania for the management of both Type I and Type 2 diabetes [8]. The plant has found similar use in Trivandrum and Kanyakumari Districts in India. Studies have found C. asiatica possessing significant hypoglycemic activity in glucose tolerance test in rabbits. It was also found not to cause hypoglycemia in fasted rabbits compared to the standard tolbutamide [8]. The ethanolic extract showed an increased glycogen content in the liver, comparable to the glibenclamide standard [9]. Addtionally, the extract showed lowered serum cholesterol and total lipid level $[9,10]$. Methanolic extract was found to be more effective than ethanolic extract in lowering blood glucose [9]. However, may aspects of basic mechanism of action of $C$. asiatica still remain unclear to date. The aim of the current study is to paint a comprehensive picture of effects $C$. asiatica on sucrose breakdown and glucose absorption, insulin release, and intestinal enzyme functions. Our study helps to identify the particular organ or organ system responsible for the previously seen hypoglycemic activity of this plant.

\section{Methods}

\section{Plant collection and processing}

C. asiatica was collected as whole plant from University Ayurvedic Research Centre (UARC), Jahangirnagar University, Dhaka, Bangladesh. The plant was identified by a botanical taxonomist prior to further processing and a voucher specimen was deposited at the National Hebarium at Mirpur, Dhaka, Bangladesh. The whole plant was cleaned off of dirt and other debris and then thoroughly washed under running tap water. The plant was then air-dried in an oven at $40^{\circ} \mathrm{C}$ and milled into a fine powder. $100 \mathrm{gm}$ of this powder was then dissolved in $1 \mathrm{~L}$ ethanol, and shaken in an orbital shaker (550 rpm for $48 \mathrm{hrs}$ ). The mixture was then filtered using a fine muslin cloth to remove the coarse insoluble particles. The fine particles were forced to sediment by centrifugation (1500 rpm for 10 mins). The supernatant was carefully pipetted out and was further filtered using a Whatman filterpaper. The filtrate was then concentrated by vacuum evaporation using the Soxhlet apparatus (Electrothermal $^{\mathrm{Ts}}$ Soxhlet extractor, UK). The concentrate was left in a refrigerator for 7 days to remove further water, converting it into a gummy substance. This then underwent freeze drying at $-55^{\circ} \mathrm{C}$ to obtain a fine powder. The fine powder extract was kept in Scott bottles along with silica gel sachets (desiccant) until further use.

\section{Animal handling}

Both the healthy and Type 2 diabetic rats (Long Evan type) were bred in the animal house of the Department of Pharmacy Practice, North South university. The healthy rats weighted about 180-220 gm while the Type 2 diabetic rats weighed about 160-180 gm at the time of the experiment. All test animals were kept in the North South University Animal house at an ambient temperature of $22 \pm 5^{\circ} \mathrm{C}$ and humidity of $50-70 \% .12 \mathrm{hrs}$ day-night cycle was maintained to avoid fluctuations in the circadian rhythm. Standard rat pellets and filtered drinking water were made available to the test animals ad libitum throughout the experiment apart from the period of fasting prior to certain tests. During fasting only water was given. During most experimental period, the rats were kept in translucent plastic cages with wood shavings provided as bedding. Animals undergoing fasting were placed in grilled bottomed cages, with no bedding, to prevent corpophagy. The designed experimental protocol was designed and subsequently approved by the Ethics Committee on Animal Research, North South University, following the "Revised guide for the care and use of laboratory animals by American Physiological Society" [11].

\section{Diabetes induction}

Type 2 diabetes was induced in the rats by an intraperitoneal injection of streptozotocin (STZ) in citrate buffer solution at a dose of $90 \mathrm{mg} / \mathrm{kg}$. Rat new-borns, less than of $48 \mathrm{hrs}$ age weighing $7 \mathrm{gm}$ were chosen for the procedure. Experiments were conducted three months after the STZ injection. The type 2 diabetic rats were selected for the experiment after conducting an oral glucose tolerance test (OGTT) and only the diabetic model rats with blood glucose levels of 8-12 mmol/L under fasting conditions were selected for the experiments [12].

\section{Acute effects of ethanolic extracts of $C$. asiatica on glucose homeostasis}

To evaluate effects on fasting blood glucose, the $C$. asiatica extract (250 mg/kg, $500 \mathrm{mg} / \mathrm{kg}$ and $1000 \mathrm{mg} / \mathrm{kg}$ ) was suspended in distilled water and orally administered to $12 \mathrm{~h}$ fasted rats. The control animals received an equal volume of distilled water.

Effects on glucose tolerance were similarly evaluated by administration of $C$. asiatica extracts together with glucose ( $2.5 \mathrm{~g} / 10 \mathrm{ml}$ per $\mathrm{kg}$ body weight) after a fasting period of $12 \mathrm{~h}$. Control group received only glucose solution.

In either cases blood was collected from the tail vein, serum separated by centrifugation and stored at $-22^{\circ} \mathrm{C}$ 
until further analysis. Blood glucose was analysed by GOD-PAP method [13] (glucose kit, Randox ${ }^{\mathrm{xt}}$, UK).

To evaluate chronic effects of $C$. asiatica, type 2 diabetic rats were given extract at $250,500,1000 \mathrm{mg} / \mathrm{kg}$ doses by gavage, twice daily for $28 \mathrm{~d}$. Control rats were similarly administered water alone $(10 \mathrm{ml} / \mathrm{kg}$ body weight). Blood samples were collected from the cut tip of the tail at the times indicated in the figures. Serum was separated by centrifugation, stored and analysed as mentioned above.

\section{Effects of C. asiatica on plasma Insulin}

Blood was drawn from Type 2 diabetic rats, $1 \mathrm{hr}$ after administration of $C$. asiatica. The amount of insulin released from the pancreas in-vivo, was determined using, Rat Insulin ELISA Kit (Crystal Chem ${ }^{\text {Tw }}$, USA).

\section{Effects of $C$. asiatica on Insulin secretion from isolated pancreatic Islets}

Pancreatic islets were isolated by collagenase digestion with minor modifications as previously described [14]. The amount of insulin released from the isolated islets was determined by, Rat Insulin ELISA Kit (Crystal Chem ${ }^{\mathrm{rn}}$, USA).

\section{Effects of C. asiatica on liver glycogen content}

Breifly, the liver was weighed and finely homogenized with $20 \mathrm{ml}$ of $5 \%$ trichloroacetic acid (TCA). The proteins precipitated, which was filtered off, and the clear filtrate was analysed for glycogen. The liver glycogen content was determined following the anthrone method as described previously [15].

\section{Effects of $C$. asiatica on intestinal glucose absorption}

An in-situ intestinal perfusion technique [16] was used to determine the effect of $C$. asiatica intestinal absorption of glucose in $36 \mathrm{~h}$ fasted non-diabetic rats anaesthetized using Ketamine $(80 \mathrm{mg} / \mathrm{kg})$. Ethanol extract of C. asiatica (5 mg/mL, $10 \mathrm{mg} / \mathrm{ml}, 20 \mathrm{mg} / \mathrm{mL}$ equivalent to $0.25 \mathrm{mg} /$ $\mathrm{kg}, 0.5 \mathrm{~g} / \mathrm{kg}, 1 \mathrm{~g} / \mathrm{kg}$ ) was suspended in Krebs Ringer buffer, along with glucose $(54 \mathrm{~g} / \mathrm{l})$. These were passed through rat pyloris via a butterfly cannula and the perfusate collected by means of a tube inserted at the end of ileum. The control group was perfused with Krebs Ringer buffer along with glucose only. Perfusion was carried out at a rate of $0.5 \mathrm{ml} / \mathrm{min}$ for $30 \mathrm{~min}$ at $37^{\circ} \mathrm{C}$. The results were presented as percentage of absorbed glucose, calculated from the percentage change in the amount of glucose in solution before and after the perfusion.

\section{Effects of $C$. asiatica on sucrose absorption from the gut} The effect of $C$. asiatica on sucrose absorption from gastroinstestinal was assayed by determining the unabsorbed sucrose content following oral sucrose load by Six-Segment Study as described by Hannan et al. [17]. $12 \mathrm{~h}$ fasted, type 2 diabetic rats were administered $50 \%$ sucrose solution per oral ( $2.5 \mathrm{~g} / \mathrm{kg}$ body mass) along with three doses of C. asiatica $(250 \mathrm{mg} / \mathrm{kg}, 500 \mathrm{mg} / \mathrm{kg}$, $1000 \mathrm{mg} / \mathrm{kg}$ ) and equal volume of water for control. Blood was sampled at the following time intervals, 30, 60,120 and $240 \mathrm{~min}$, after sucrose load for the quantification of blood glucose. At these time intervals, some of the rats were sacrificed for determining unabsorbed sucrose contents of the GI tract. The GI tract was excised and separated into six segments: the stomach, the upper $20 \mathrm{~cm}$, middle and lower $20 \mathrm{~cm}$ of the small intestine, the caecum and the large intestine. Each segment was rinsed with acidified ice-cold saline followed by centrifugation at $3000 \mathrm{rpm}(1000 \mathrm{~g})$ for $10 \mathrm{~min}$. The supernatant was pipette out and boiled for $2 \mathrm{~h}$, in sulphuric acid, to hydrolyse the sucrose. The sulfuric acid was later neutralized by $\mathrm{NaOH}$ solution. Both plasma glucose concentration, and the amount of glucose released from residual sucrose in the GI tract was determined. The GI sucrose content was calculated from the amount of liberated glucose [18].

\section{Effects of $C$. asiatica on gut motility}

GI motility was determined by means of $\mathrm{BaSO}_{4}$ milk following the previously described method of Chattarjee [19]. $\mathrm{BaSO}_{4}$ milk was prepared by mixing $\mathrm{BaSO}_{4}$ as $10 \%(\mathrm{w} / \mathrm{v})$ in $0.5 \%$ carboxy methyl cellulose to form a suspension. The ethanol extract was administered per oral, $1 \mathrm{hr}$ before the oral administration of $\mathrm{BaSO}_{4}$ milk. Control group was administered distilled water only $(10 \mathrm{ml} / \mathrm{kg})$. Rats belonging to all groups were sacrificed 15 mins after $\mathrm{BaSO}_{4}$ administration. The distance travelled by $\mathrm{BaSO}_{4}$ milk was measured, and represented as a percentage of total length of the small intestine (from pylorus to ileocaecal junction).

\section{Effects of $C$. asiatica on intestinal disaccharidase enzyme activity}

The assay was conducted following the procedure as described previously by Hannan et al. [20]. The ethanol extract of C. asiatica (250, 500 and $1000 \mathrm{mg} / \mathrm{kg}$ ) was administered by gastric gavage to $20 \mathrm{hrs}$ fasted nondiabetic rats. After $60 \mathrm{mins}$, the rats were sacrificed and the small intestine was isolated, cut longitudinally, rinsed with ice-cold saline and homogenized in $10 \mathrm{ml}$ saline $(0.9 \%$ $\mathrm{NaCl})$. Aliquots of homogenate were incubated with $40 \mathrm{mM}$-sucrose at $37^{\circ} \mathrm{C}$ for $60 \mathrm{~min}$. The amount of protein was determined by DC ${ }^{\mathrm{mm}}$ Protein Kit (Bio Rad, USA). Disaccharidase activity was determined from the glucose concentration converted from sucrose as $\mu \mathrm{mol} / \mathrm{mg}$ protein $/ \mathrm{h}$.

\section{Effect of C. asiatica on body mass, food and water intake of type 2 diabetic rats}

The rats kept for chronic study were provided with sufficient amounts of food and water for one day. At the end of the day, the mass of food and volume of water intake 
was recorded. The change in body mass of the rats was also monitored at periods as shown in the graph.

\section{Effects of $C$. Asiatica on organ weight ratio of liver and pancreas}

The animals used on the chronic study were sacrificed by cervical dislocation at the end of the study period and the liver and pancreas were excised. They were cleaned of fats, and were kept moist at all times keeping them in normal saline $(0.9 \%$ of $\mathrm{NaCl})$. The wet mass of the organs were immediately weighed using a digital balance. The weight of the pancreas was expressed as mg/100 gm of body weight while the weight of the live was represented as gm/ $100 \mathrm{gm}$ of body weight, as shown in the graphs.

\section{Chronic effects of ethanolic extracts of $C$. asiatica on serum lipid profile of type 2 diabetic model rats}

To assess chronic effects of $C$. asiatica, type 2 diabetic model rats were ethanol extract at three dosages $(250 \mathrm{mg} / \mathrm{kg}, 500 \mathrm{mg} / \mathrm{kg}$ and $1000 \mathrm{mg} / \mathrm{kg}$ ) by gastric gavages, twice daily for $28 \mathrm{~d}$. Control rats were administered only distilled water of similar volume. Blood samples were collected from the tail vein, at times, indicated in the graphs. Serum was separated by centrifugation and stored at $22^{\circ} \mathrm{C}$ until further analysis.

\section{Effect of C. asiatica on jejunal nutrient absorption by glucose dialysis-tube retardation assay}

Dry, precut dialysis sacs (inflated diam. approx. $16 \mathrm{~mm}$, length $=30 \mathrm{~cm}$, Sigma Aldrich ${ }^{\mathrm{tw}}$, USA) were soaked in $1 \mathrm{~g}$ sodium azide/L. The bag was loaded with $6 \mathrm{~mL}$ sodium azide $(1 \mathrm{gm} / \mathrm{L})$ and $36 \mathrm{mg}$ glucose alone (the control sac) or after addition of fine powder of $C$. asiatica. The dry fibrous powder was wetted by an aqueous solution of sodium azide $(1 \mathrm{~g} / \mathrm{L})$ for $14 \mathrm{~h}$ prior to the experiment. The sacs were closed at the ends and hung in a solution of $100 \mathrm{~mL}$ of sodium azide $(1 \mathrm{~g} / \mathrm{L})$ and then placed in a stirred bath at $37^{\circ} \mathrm{C}$ for $1 \mathrm{hr}$. At 30 and $60 \mathrm{mins}$ time interval, $2 \mathrm{~mL}$ of the dialysate was analyzed for glucose by the GOD-PAP method as previously described.

The effect of fiber on nutrient absorption was indicated by the glucose dialysis retardation index:

$$
-\left(\frac{\text { Total glucose diffused from sac containing fiber } \times 100}{\text { Total glucose diffused from sac containing no fiber present }}\right)
$$

\section{Effect of $C$. asiatica on a-amylase activity}

The effects of $C$. asiatica powder on starch digestibility was determined as a function of time in a fiber-enzyme-starch mixture system using a dialysis membrane with a cutoff molecular weight of 12,000 da (inflated diam. approx. $16 \mathrm{~mm}$, length $=30 \mathrm{~cm}$, Sigma Aldrich ${ }^{\mathrm{Tm}}$, USA) as previously described with minor modifications [15]. A solution was prepared by mixing $0.2 \mathrm{~g}$ of powdered $C$. asiatica and $0.04 \mathrm{~g} \alpha$-amylase (obtained from human saliva, Sigma Aldrich $^{\text {tw }}$ USA) in $10 \mathrm{ml}$ of potato starch solution $(4 \mathrm{~g} /$ $100 \mathrm{ml}$ ) was dialyzed in $200 \mathrm{ml}$ deionised water at $37^{\circ} \mathrm{C}$. Following the incubation period, 10, 30, 60, and $120 \mathrm{~min}$, glucose concentration in the dialysate solution was assayed using the GOD-PAP method as described previously. The control was run without the addition of powder.

\section{Determination of glucose-adsorption capacity}

The assay was conducted following the procedure by $\mathrm{Ou}$ et al. [21], where the glucose-adsorption ability $(\mathrm{mM} / \mathrm{mol} /$ $\mathrm{gm})$ was measured by mixing $1 \mathrm{~g}$ of insoluble plant powder or Carboxymethyl cellulose (CMC) with $100 \mathrm{~mL}$ of glucose solution at a constant temperature of $37^{\circ} \mathrm{C}$ for $6 \mathrm{hrs}$. This was then followed by centrifugation at $3500 \mathrm{rpm}$ for $15 \mathrm{~min}$. Glucose concentration in the supernatant was assayed using GOD-PAP method as previously described.

\section{Statistical analysis}

Statistical tests were conducted using Statistical Package for Social Science Software (SPSS) ver. 20 (IBM, Inc., Chicago, IL, USA). Results are presented as means \pm SEM. Data from experimental groups were compared using unpaired Student's $t$ test and the Mann-Whitney $U$ test, as required. Experiments with data being collected at several time intervals, were analyzed using repeated measures ANOVA followed by Bonferroni adjustment ensuring an error margin within $\leq 5 \%$. One-way ANOVA was carried out and pair-wise comparisons were made with the control group using Dunnett's test to maintain an acceptable error margin of $5 \%$. A two-tailed $P$ value of $<0.05$ was considered statistically significant.

\section{Results}

\section{Acute and chronic effects of C. asiatica on glucose} homeostasis

Oral administration of C. asiatica, at any doses, did not alter the hyperglycaemic condition of fasted type 2 diabetic rats (Figure 1). The extract, at $1000 \mathrm{mg} / \mathrm{Kg}$ dose, improved glucose homeostasis at $60 \mathrm{~min}$ and $120 \mathrm{~min}$, when administered along with glucose load $(\mathrm{p}<0.05$; Figure 2). However, the extract did not show any effect on plasma insulin level (Figure 3).

After a 28 days chronic study of C. asiatica (three doses, administered twice daily) on type 2 diabetic rats, $1000 \mathrm{mg} / \mathrm{Kg}$ dose showed significant reduction in serum glucose level ( $\mathrm{p}<0.05$; Figure 4).

\section{Effect of $C$. asiatica on serum glucose after sucrose load} All the doses of $C$. asiatica showed a significant $(\mathrm{p}<0.05)$ suppression of serum glucose level at 30 min compared to control, where peak serum glucose was observed after administration of sucrose load. $1000 \mathrm{mg} / \mathrm{Kg}$ dose of 


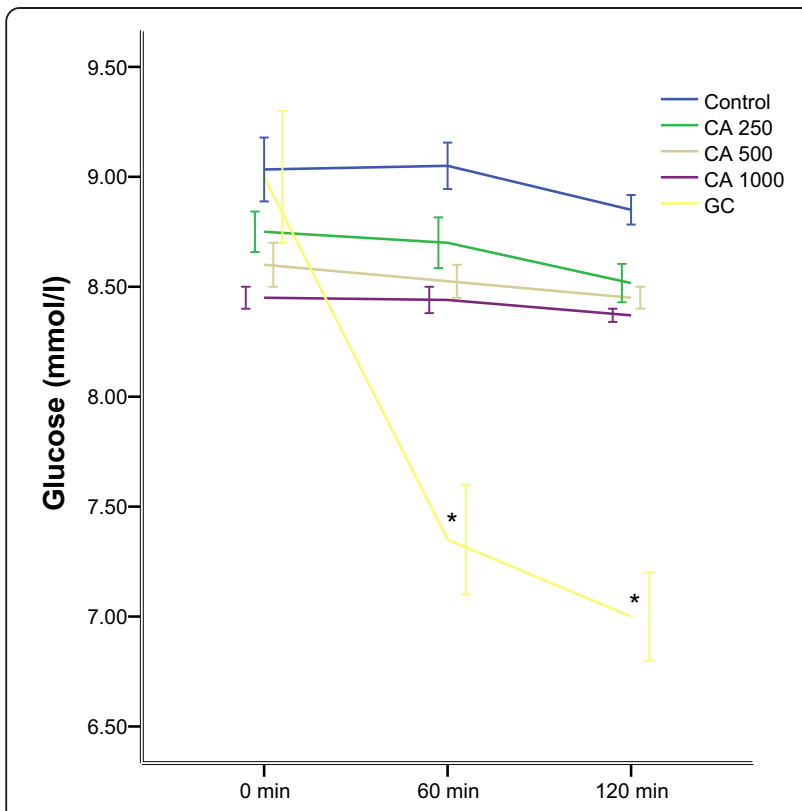

Figure 1 Effects of ethanol extract of $C$. asiatica (CA) on fasting blood glucose level in type $\mathbf{2}$ diabetic rats. Values are means and standard deviations represented by vertical bars $(n=10)$. Fasted rats were given ethanol extract of C. asiatica $(250 \mathrm{mg} / \mathrm{kg}, 500 \mathrm{mg} / \mathrm{kg}$, and $1000 \mathrm{mg} / \mathrm{kg}$ body weight) or Glibenclamide (GC) $(0.5 \mathrm{mg} / \mathrm{Kg}$ ) or only water (control) by oral administration. Mean values marked with an asterisk (*) were significantly different from those of respective control rats $(p<0.05)$ (derived from repeated-measures ANOVA and adjusted using Bonferroni correction).

C. asiatica maintained this trend of suppression of glucose level at $60 \mathrm{~min}$ too (Figure 5).

\section{Effect of $C$. asiatica on intestinal glucose absorption}

$1000 \mathrm{mg} / \mathrm{Kg}$ doses of $C$. asiatica extract, when perfusated with glucose, showed significant $(\mathrm{p}<0.05)$ reduction in the percentage of glucose absorption during most of the perfusion period (Figure 6).

\section{Effect of C. asiatica on unabsorbed sucrose content in the} gastrointestinal tract

Upon oral administration of sucrose along with $C$. asiatica $(1000 \mathrm{mg} / \mathrm{Kg})$, significant amount of unabsorbed sucrose was remained in the stomach, upper, middle, and lower intestine at $30 \mathrm{~min}$ and $1 \mathrm{~h}$. This amount of residual sucrose remained significant in caecum and large intestine till $4 \mathrm{~h}(\mathrm{p}<0.05$; Figure 7$)$.

\section{Effect of C. asiatica on gut motility and intestinal disaccharidase enzyme activity}

C. asiatica extract increased the gastrointestinal motility significantly $(\mathrm{p}<0.05)$ at both $500 \mathrm{mg} / \mathrm{Kg}$ and $1000 \mathrm{mg} /$ $\mathrm{Kg}$ doses. However, the extract showed significant ( $\mathrm{p}>$ 0.05 ) inhibition of disaccharidase enzyme activity only at $1000 \mathrm{mg} / \mathrm{Kg}$ dose (Figure 8).

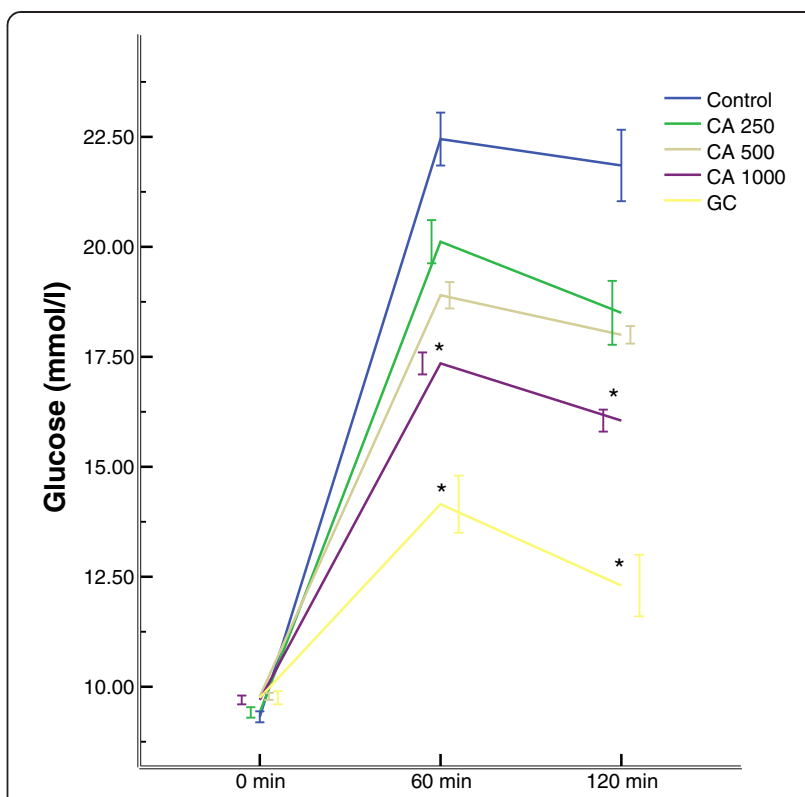

Figure 2 Effects of ethanol extract of C. asiatica (CA) on glucose tolerance in type 2 diabetic rats. Values are means and standard deviations represented by vertical bars $(n=11)$. Fasted rats were given ethanol extract of C. asiatica $(250 \mathrm{mg} / \mathrm{kg}, 500 \mathrm{mg} / \mathrm{kg}$, and $1000 \mathrm{mg} / \mathrm{kg}$ body weight) or Glibenclamide (GC) $(0.5 \mathrm{mg} / \mathrm{Kg})$ or only water (control) by oral administration with glucose $(2.5 \mathrm{~g} / \mathrm{kg}$ body weight). Mean values marked with an asterisk $\left(^{*}\right)$ were significantly different from those of respective control rats $(p<0.05)$. (Derived from repeated-measures ANOVA and adjusted using Bonferroni correction).

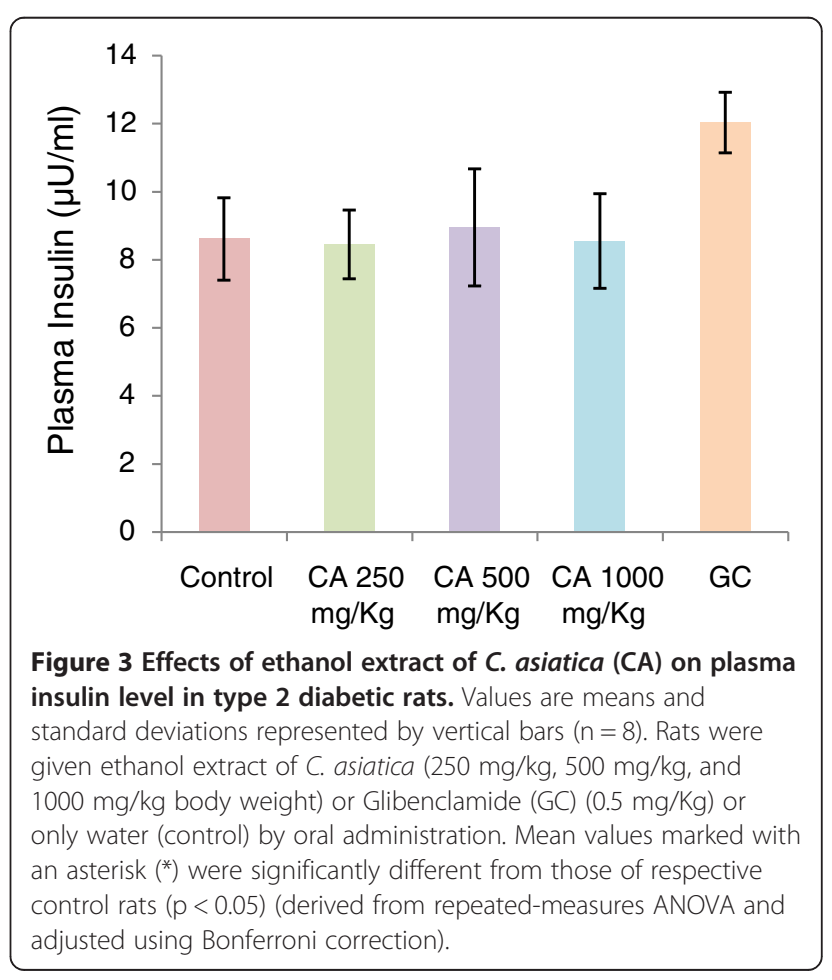




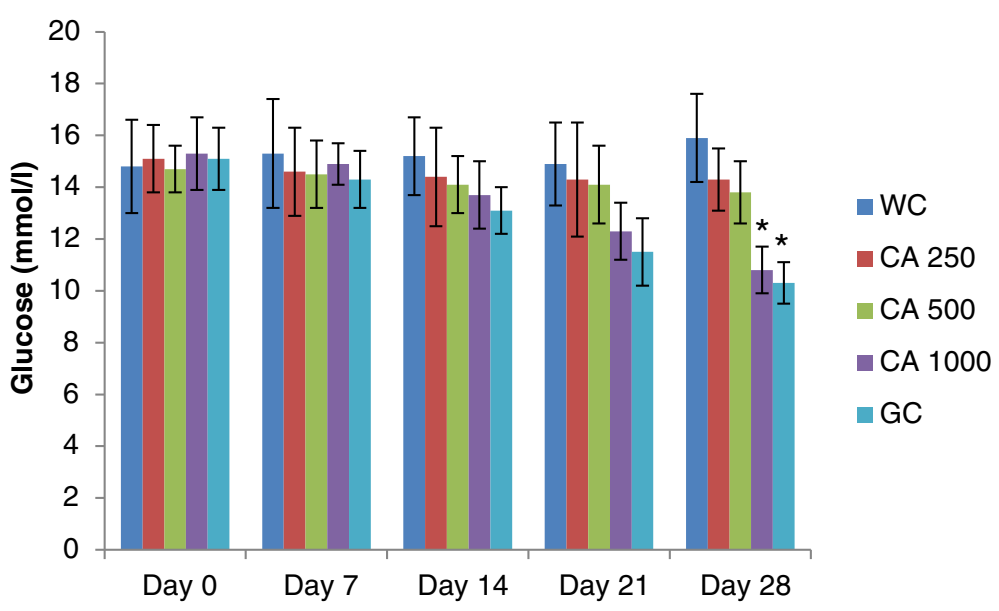

Figure 4 Effects of ethanol extract of $C$. asiatica (CA) on fasting serum glucose level in type 2 diabetic rats after 28 days of feeding. Values are means and standard deviations represented by vertical bars $(n=10)$. Fasted rats were given ethanol extract of $C$. asiatica $(250 \mathrm{mg} / \mathrm{kg}$, $500 \mathrm{mg} / \mathrm{kg}$, and $1000 \mathrm{mg} / \mathrm{kg}$ body weight) or Glibenclamide (GC) $(0.5 \mathrm{mg} / \mathrm{Kg})$ or only water (water control, WC) by oral administration for a period of 28 days. Mean values marked with an asterisk $\left(^{*}\right)$ were significantly different from those of respective control rats $(p<0.05)($ derived from repeated-measures ANOVA and adjusted using Bonferroni correction).
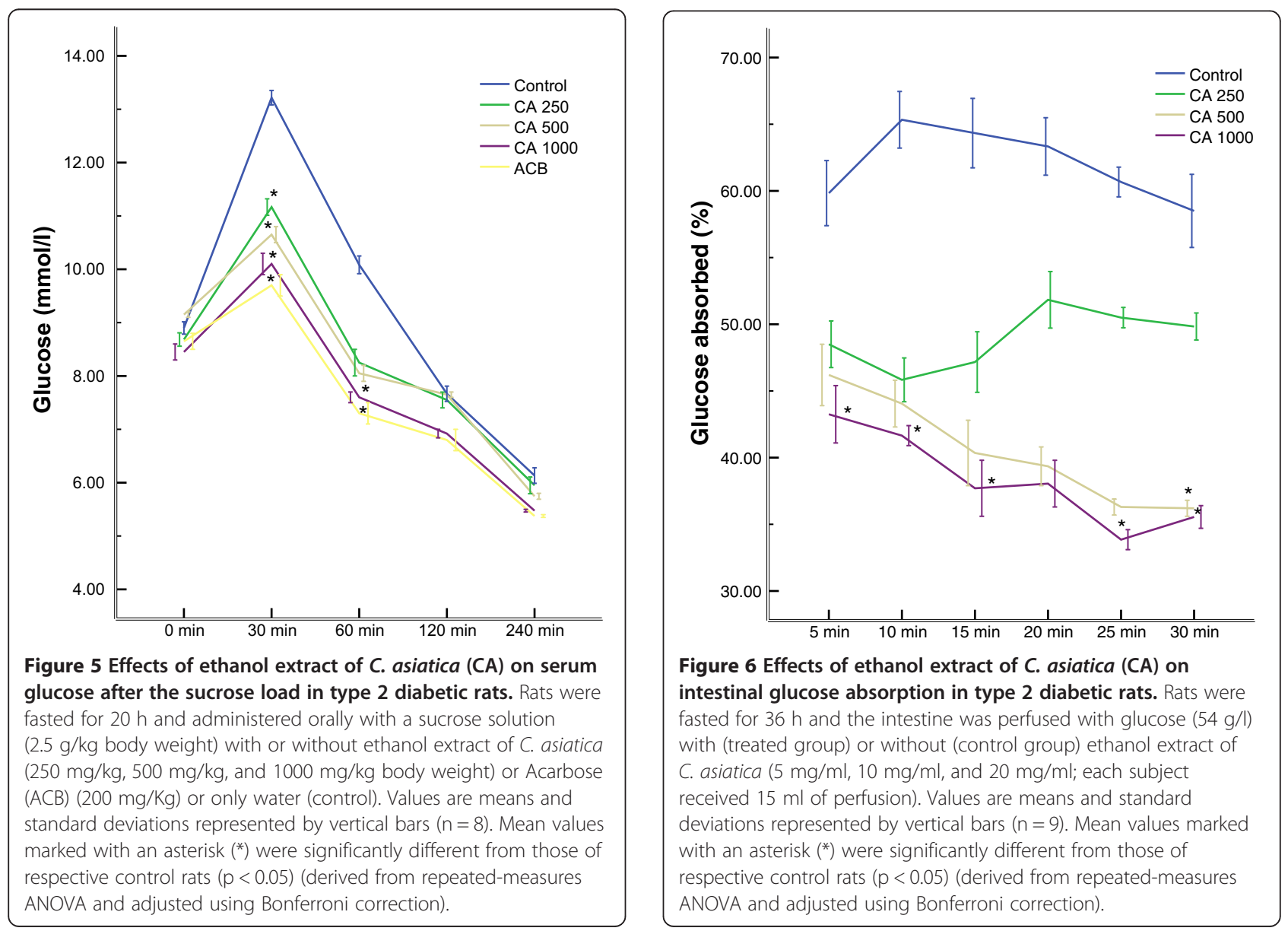


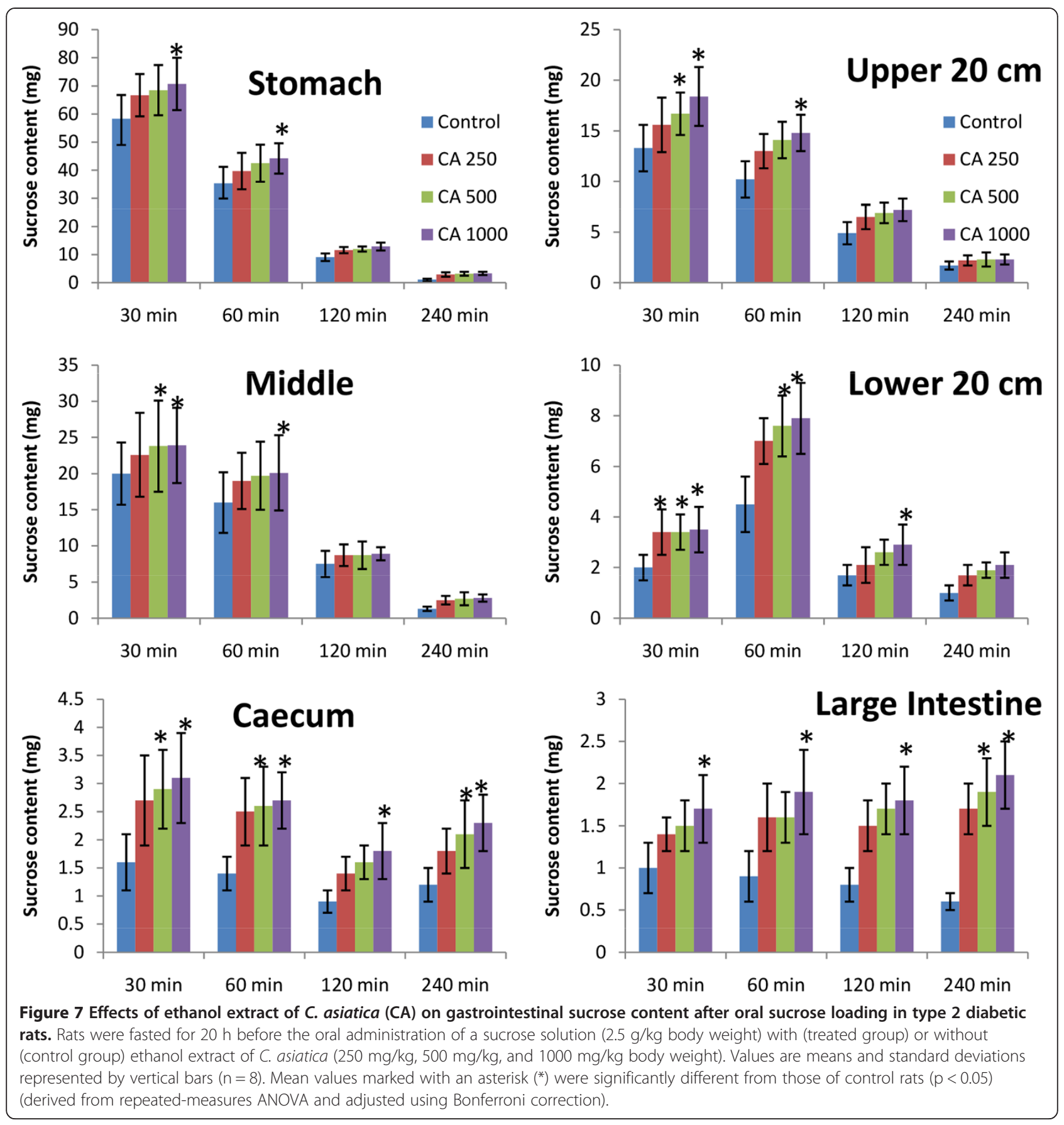

Effect of C. asiatica on insulin secretion from isolated rat islets

C. asiatica extract, at any dose, did not induce any stimulatory activity on insulin secretion from isolated islets in the presence of both $3 \mathrm{mM}$ and $11 \mathrm{mM}$ glucose (Table 1).

Chronic effect of C. asiatica on Liver glycogen, organ weight, food habit, and serum lipid profile

After the 28 days long study of C. asiatica (three doses, administered twice daily) on type 2 diabetic rats, no significant changes were seen in the liver glycogen content, liver weight, and pancreas weight (Figure 9). However, significant reductions in body weight, food intake, and water intake were observed at the end of the study $(\mathrm{p}<0.05$; Figure 10).

C. asiatica extract of $1000 \mathrm{mg} / \mathrm{Kg}$ dose improved serum lipid profile of type 2 diabetic rats after 28 days of twice daily oral feeding. It decreased the level of serum triglyceride, low density lipoprotein (LDL), and cholesterol significantly, which was comparable to the effect of 


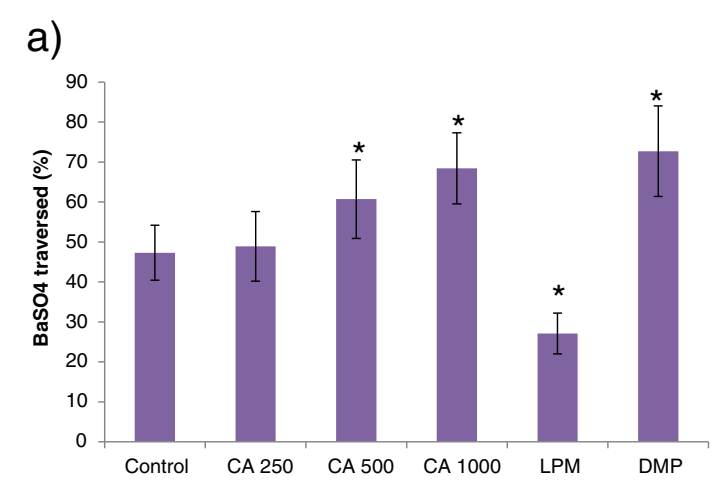

b)

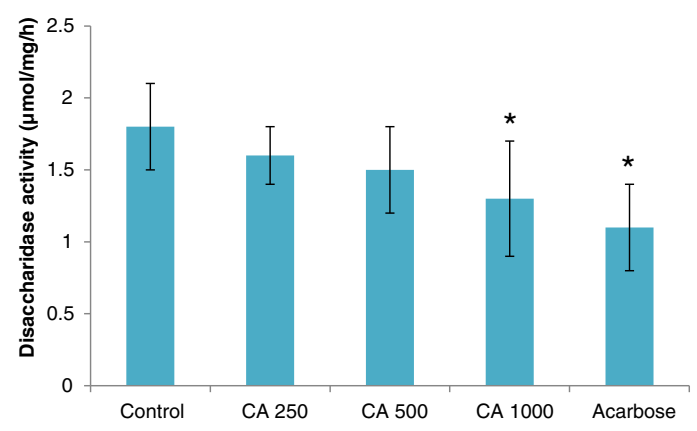

Figure 8 Effects of ethanol extract of $C$. asiatica (CA) on a) gastrointestinal motility (by BaSO4 traversed) and b) intestinal disaccharidase activity in type $\mathbf{2}$ diabetic rats. Rats were fasted for $20 \mathrm{~h}$ before the oral administration of ethanol extract of C. asiatica $(250 \mathrm{mg} / \mathrm{kg}, 500 \mathrm{mg} / \mathrm{kg}$, and $1000 \mathrm{mg} / \mathrm{kg}$ body weight) or water (control). Enzyme activity was determined and BaSO4 was administered at $60 \mathrm{~min}$. Motility was measured over the following $15 \mathrm{~min}$. Acarbose (ACB) $(200 \mathrm{mg} / \mathrm{Kg})$ and Loperamide (LPM) $5 \mathrm{mg} / \mathrm{Kg})$ \& Domperidone (DMP) $(10 \mathrm{mg} / \mathrm{Kg})$ were used as reference controls for disaccharidase activity test and gastrointestinal motility test respectively. Values are means and standard deviations represented by vertical bars $(n=12)$. Mean values marked with an asterisk $\left(^{*}\right)$ were significantly different from those of diabetic control rats $(p<0.05)$ (derived from repeated-measures ANOVA and adjusted using Bonferroni correction).

reference drug Glibenclamide $(\mathrm{p}<0.05$; Figure 11). Moreover, the extract increased the level of high density lipoprotein (HDL) significantly ( $\mathrm{p}<0.05$; Figure 11$)$.

\section{Effect of C. asiatica powder on In vitro glucose dialysis retardation index (GDRI)}

C. asiatica powder at different doses reduced the amount of glucose present in the dialysate. However, it was significant only for $1000 \mathrm{mg}$ powder group; GDRI $45.8 \%$ and $48.54 \%$ at $30 \mathrm{~min}$ and $60 \mathrm{~min}$ respectively $(\mathrm{p}<0.05$; Table 2).

\section{Effect of $C$. asiatica powder on a-amylase activity}

The effect of $C$. asiatica powder on starch digestibility was determined by the alteration in the glucose
Table 1 Effect of ethanolic extract of CA (Centella asiatica) on insulin secretion from isolated rat islets

\begin{tabular}{|c|c|c|}
\hline \multirow[t]{2}{*}{ Group } & \multicolumn{2}{|c|}{ Insulin secretion (ng/mg islet protein) } \\
\hline & Glucose: $3 \mathrm{mM}$ & Glucose: $11 \mathrm{mM}$ \\
\hline Control & $2.99(2.65-4.27)$ & $5.41(4.91-9.27)^{*}$ \\
\hline CA $20 \mu \mathrm{g} / \mathrm{ml}$ & $2.78(2.19-3.56)$ & $5.03(4.24-8.54)$ \\
\hline CA $40 \mu \mathrm{g} / \mathrm{ml}$ & $3.09(2.43-3.82)$ & $5.11(4.39-7.98)$ \\
\hline CA $80 \mu \mathrm{g} / \mathrm{ml}$ & $2.85(2.07-3.69)$ & $5.24(4.78-8.61)$ \\
\hline Glibenclamide $(10 \mu \mathrm{g} / \mathrm{l})$ & $5.89(4.34-6.95)^{*}$ & $8.92(7.67-9.86)^{*}$ \\
\hline
\end{tabular}

Isolated rat islets were incubated for $60 \mathrm{~min}$ with ethanol extract of Centella asiatica $(10,20$, and $30 \mathrm{mg} / \mathrm{ml})$ in the presence of 3 or $11 \mathrm{mM}$ glucose. Data are presented as median (range), $n=5$. Mann-Whitney $U$-test was used to evaluate statistical significance. ${ }^{*} \mathrm{p}<0.05$ compared with control $(3 \mathrm{mM}$ glucose without extract).

concentration in the dialysate with time. There was no significant change, compared to control, in the glucose content at $10 \mathrm{~min}$. However, the glucose content in the dialysate was significantly increased, compared to control, at $30 \mathrm{~min}, 1 \mathrm{~h}$, and $2 \mathrm{~h}(\mathrm{p}<0.05$; Table 3$)$.

\section{Effect of C. asiatica powder on In vitro glucose adsorption capacity}

C. asiatica powder showed high capacity of glucose adsorption in the presence of different levels of glucose in the solution. This activity of glucose adsorption was found to persist from higher level of glucose to even very low level of glucose present in the solution (Table 4).

\section{Discussion}

C. asiatica is a plant, native to the Indian Subcontinent, continental Asia, Australia and Papua New Guinea [22]. It is indigenously used to treat a wide range of pathological conditions including diabetes, which provides a solid ground for our current study [8-10]. Additionally, unpublished, preliminary screening data, of this plant, showed highly promising hypoglycemic activity. However, there are no reported studies on tissue level mechanism of action of $C$. asiatica. Studies have established that hyperglycemic states, during diabetes, is the initiator of diabetic tissue damage [23]. Cells damaged by hyperglycemia cannot maintain a constant internal glucose concentration, which results in acutely altered cellular metabolism and long-term changes in cellular macromolecular content [24-26]. Postprandial glucose spike causes perturbation in endothelial cell function $[27,28]$, and increased blood coagulation [29]. Hyperglycemic states also increases products of glycosylation, which has a significant influence in development of diabetic induced vascular disease [30]. Therefore, management of hyperglycemic states is an important method of diabetes control. The basic mechanism of actions of commonly used diabetic drugs are, enhanced insulin secretion, 

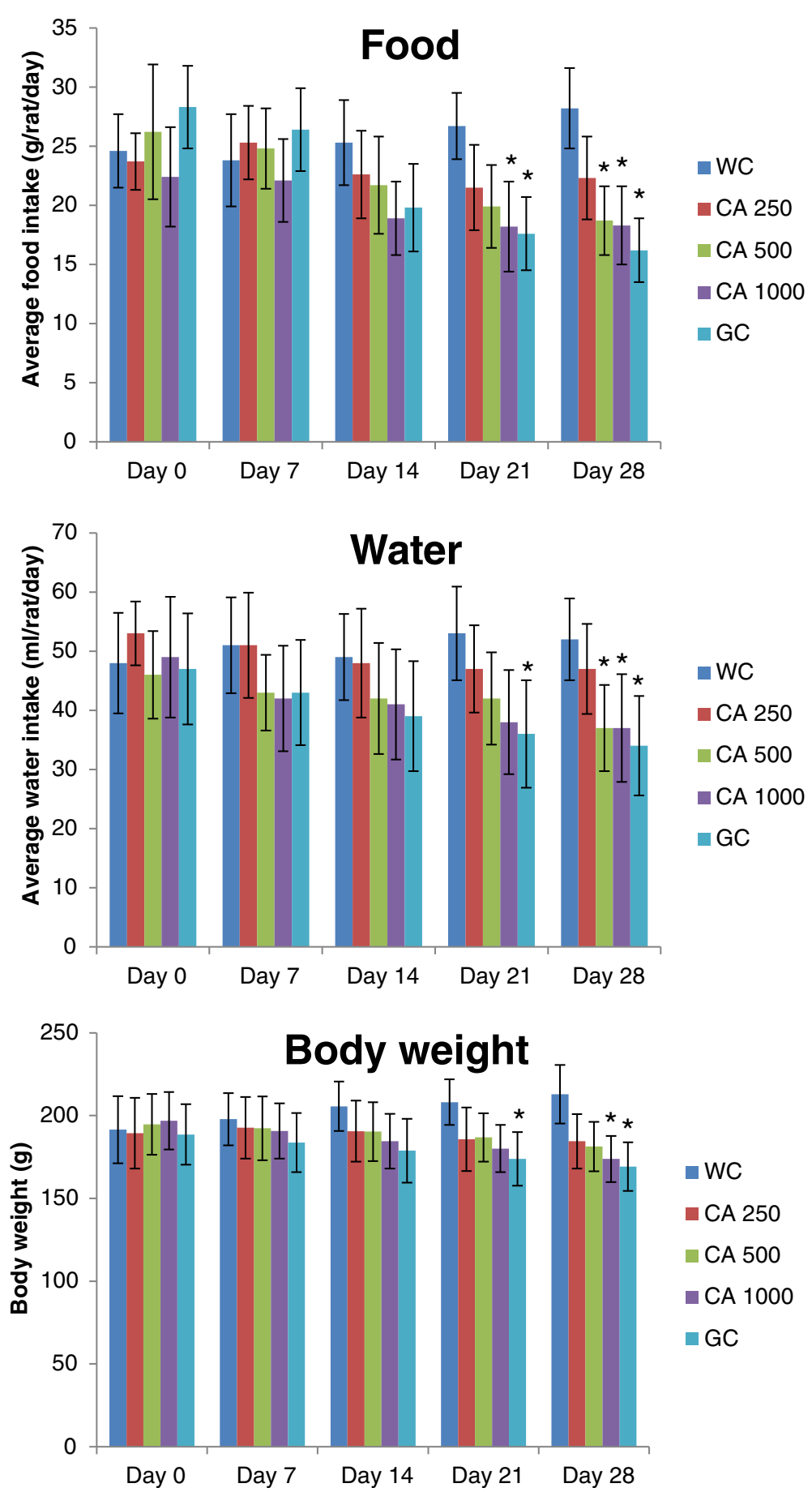

Figure 9 Effects of ethanol extract of C. asiatica (CA) on body weight, average food intake, and average water intake in type 2 diabetic rats after 28 days of feeding. Values are means and standard deviations represented by vertical bars $(n=10)$. Fasted rats were given ethanol extract of C. asiatica ( $250 \mathrm{mg} / \mathrm{kg}, 500 \mathrm{mg} / \mathrm{kg}$, and $1000 \mathrm{mg} / \mathrm{kg}$ body weight) or Glibenclamide (GC) $(0.5 \mathrm{mg} / \mathrm{Kg}$ ) or only water (control) by oral administration for a period of 28 days. Mean values marked with an asterisk $\left(^{*}\right)$ were significantly different from those of respective control rats $(p<0.05)$ (derived from repeated-measures ANOVA and adjusted using Bonferroni correction). 

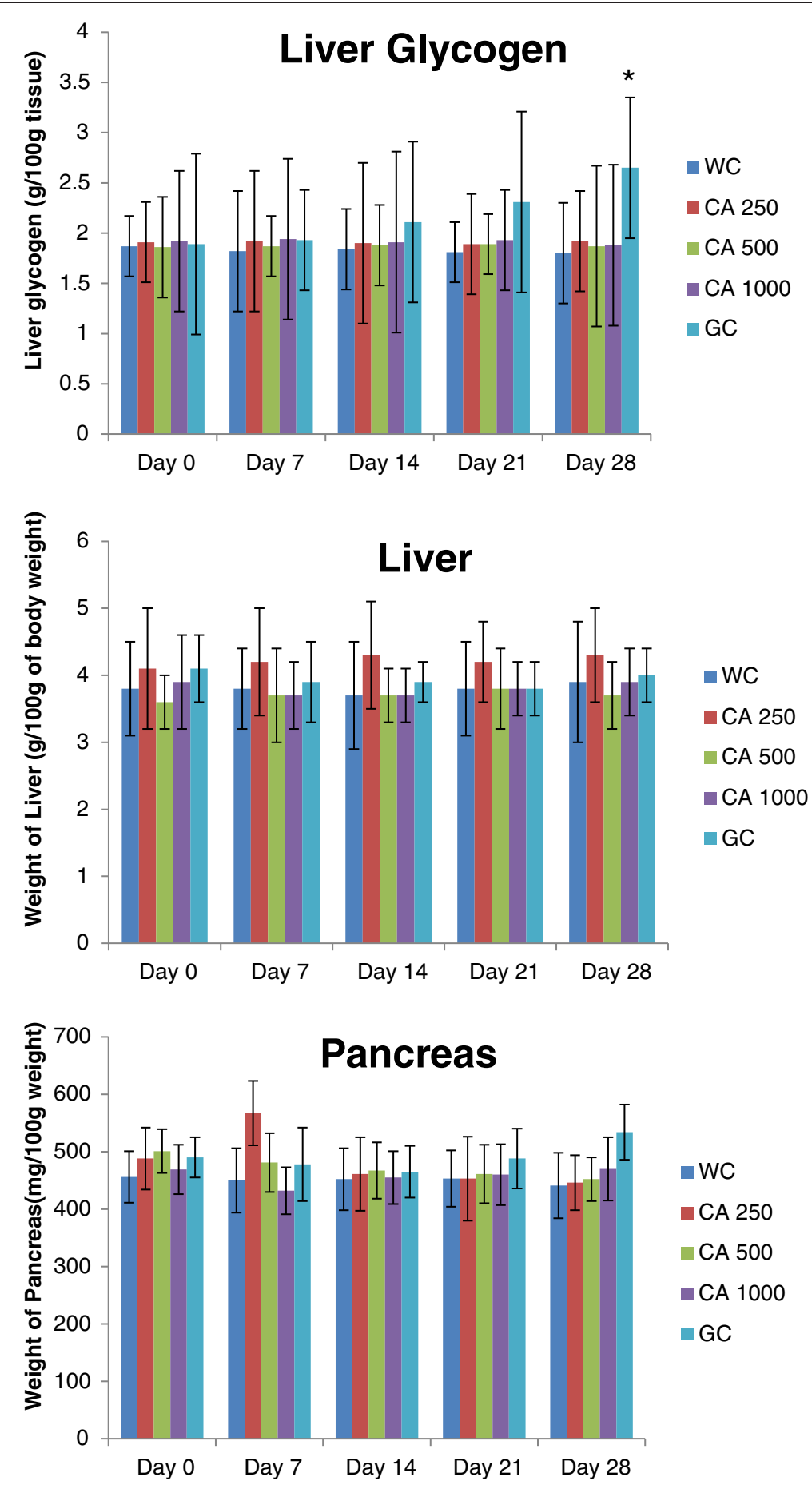

Figure 10 Effects of ethanol extract of $C$. asiatica (CA) on liver glycogen, liver weight, and pancreas weight in type 2 diabetic rats after 28 days of feeding. Values are means and standard deviations represented by vertical bars $(n=10)$. Fasted rats were given ethanol extract of C. asiatica ( $250 \mathrm{mg} / \mathrm{kg}, 500 \mathrm{mg} / \mathrm{kg}$, and $1000 \mathrm{mg} / \mathrm{kg}$ body weight) or Glibenclamide (GC) (0.5 mg/ $\mathrm{kg}$ ) or only water (water control, WC) by oral administration for a period of 28 days. Mean values marked with an asterisk $\left(^{*}\right)$ were significantly different from those of respective control rats $(p<0.05)$ (derived from repeated-measures ANOVA and adjusted using Bonferroni correction). 

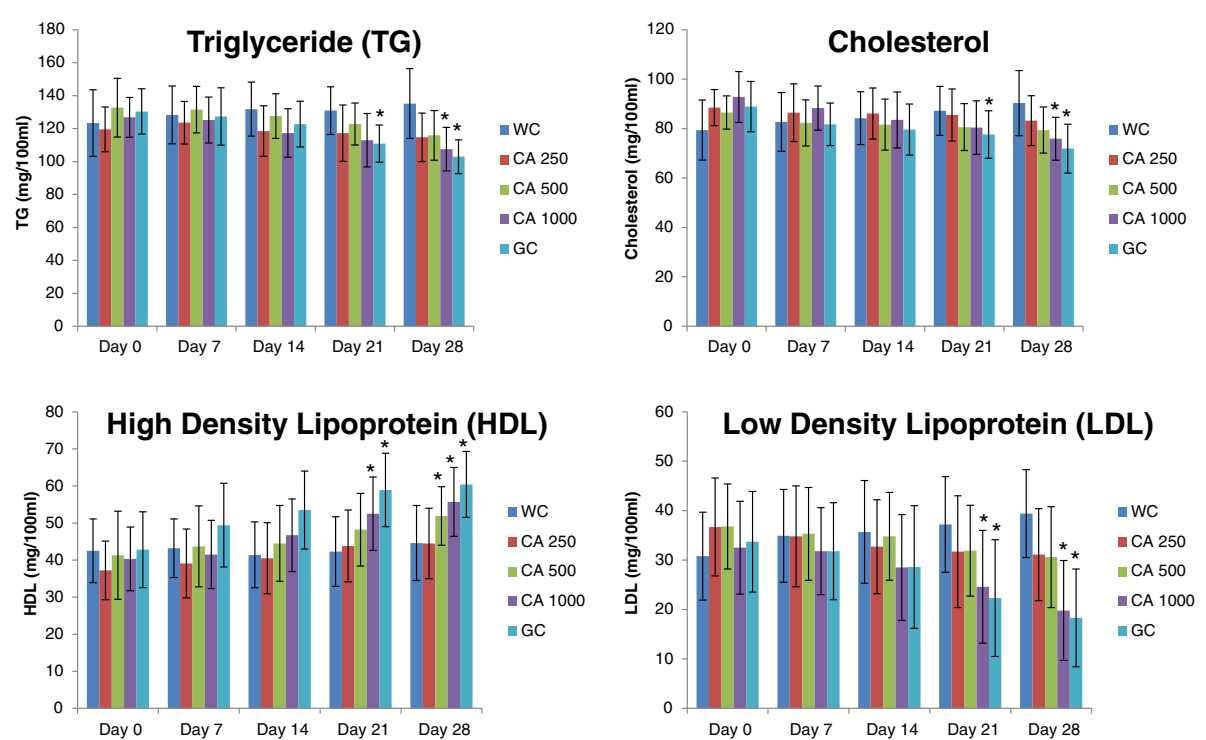

Figure 11 Effects of ethanol extract of $C$. asiatica (CA) on serum lipid profile (TG, Cholesterol, HDL, and LDL) in type 2 diabetic rats after 28 days of feeding. Values are means and standard deviations represented by vertical bars $(n=10)$. Fasted rats were given ethanol extract of C. asiatica (250 mg/kg, $500 \mathrm{mg} / \mathrm{kg}$, and $1000 \mathrm{mg} / \mathrm{kg}$ body weight) or Glibenclamide (GC) $(0.5 \mathrm{mg} / \mathrm{Kg}$ ) or only water (control) by oral administration for a period of 28 days. Mean values marked with an asterisk $\left(^{*}\right)$ were significantly different from those of respective control rats $(p<0.05)$ (derived from repeated-measures ANOVA and adjusted using Bonferroni correction).

enhanced sensitivity to insulin, improved peripheral glucose utilization, inhibition of glucose absorption, and inhibition of carbohydrate digestion [31]. In our current study, we have employed techniques, which will suggest one or more of the aforementioned modes of action.

Altered lipid metabolism is a hallmark of type 2 diabetes induced dyslipidemia, which is characterized by reduced HDL and increased LDL, triglycerides, and total cholesterol [32]. Hyperglycemia and altered lipid status, in tandem, poses a significant threat of cardiovascular complications in diabetic patients. Unattended hyperlipidemia might give rise to both micro and macro vascular complications in type 2 diabetic patients [33]. Therefore, alleviated lipid profile in patients might improve diabetes induced secondary complications. Type 2 diabetic rats treated with $1000 \mathrm{mg} / \mathrm{kg}$ of C. asiatica extract showed marked improvement in serum lipid profile at the end of our 28 days study period.

Type 2 diabetic patients have a higher incidence of obesity. It is also characterized by polyphagia and polydipsia [34]. By the end of our study period, C. asiatica treated Type 2 diabetic rats returned to a normal body weight and exhibited food and water intake comparable to healthy rats.

Studies have shown that blood glucose level in the upper normal range is a probable risk factor for cardiovascular disease, a condition, chronic in Type 2 diabetic patients [35]. In our studies, fasting blood glucose remained unaffected in Type 2 diabetic rats in all groups apart from the "Glibenclamide" control group. In glucose tolerance test, the peak glucose concentration after glucose challenge in C. asiatica treated group at $1000 \mathrm{mg} / \mathrm{kg}$

Table 2 Retarding effect of insoluble fibre of CA on the glucose movement (glucose dialysis retardation index)

\begin{tabular}{cccccc}
\hline Treatment & \multicolumn{2}{c}{ Dialysis for $\mathbf{3 0}$ min } & & \multicolumn{2}{c}{ Dialysis for $\mathbf{6 0}$ min } \\
\cline { 2 - 3 } \cline { 5 - 6 } & $\begin{array}{c}\text { Glucose in Dialysate } \\
(\mathbf{m m o l} / \mathbf{L})\end{array}$ & $\begin{array}{c}\text { Glucose dialysis retardation } \\
\text { index (\%) }\end{array}$ & & $\begin{array}{c}\text { Glucose in Dialysate } \\
(\mathbf{m m o l} / \mathbf{L})\end{array}$ & $\begin{array}{c}\text { Glucose dialysis retardation } \\
\text { index (\%) }\end{array}$ \\
\hline CA $250 \mathrm{mg}$ & $0.83 \pm 0.19$ & 30.25 & & $1.15 \pm 0.15$ & 32.75 \\
CA $500 \mathrm{mg}$ & $0.76 \pm 0.12$ & 35.29 & & $1.09 \pm 0.06$ & 36.26 \\
CA $1000 \mathrm{mg}$ & $0.65 \pm 0.09^{*}$ & 45.38 & & $0.88 \pm 0.12^{*}$ & 48.54 \\
CMC $1000 \mathrm{mg}$ & $0.62 \pm 0.11^{*}$ & 42.86 & $0.83 \pm 0.07^{*}$ & 51.46 \\
Control & $1.19 \pm 0.21$ & 0 & $1.71 \pm 0.14$ & 0 \\
\hline
\end{tabular}

Data are presented as Mean \pm SEM $(n=7)$. Glucose dialysis retardation index $=$ control $(100 \%)-$ fibre $(\%$ of control value). Mean values marked with an asterisk $(*)$ were significantly different from those of respective control groups $(p<0.05)$ (derived from repeated-measures ANOVA and adjusted using Bonferroni correction). 
Table 3 Effect of insoluble fibre of CA on starch digestibility

\begin{tabular}{ccccc}
\hline Treatment & \multicolumn{4}{c}{ Glucose in dialysate $(\boldsymbol{\mu m o l} / \mathbf{I})$} \\
\cline { 2 - 5 } & $\mathbf{1 0} \mathbf{~} \mathbf{~ i n}$ & $\mathbf{3 0} \mathbf{~}$ in & $\mathbf{6 0} \mathbf{~ m i n}$ & $\mathbf{1 2 0} \mathbf{~ m i n}$ \\
\hline CA 250 mg & $1.72 \pm 0.09$ & $4.05 \pm 0.15$ & $13.6 \pm 1.23$ & $21.7 \pm 4.10$ \\
CA $500 \mathrm{mg}$ & $1.81 \pm 0.11$ & $4.56 \pm 0.42^{*}$ & $14.3 \pm 2.32$ & $23.50 \pm 5.20^{*}$ \\
CA 1000 mg & $1.85 \pm 0.15$ & $4.88 \pm 0.50^{*}$ & $15.89 \pm 2.11^{*}$ & $26.45 \pm 4.83^{*}$ \\
CMC 1000 mg & $1.91 \pm 0.21$ & $4.94 \pm 0.34^{*}$ & $16.09 \pm 2.31^{*}$ & $26.57 \pm 5.34^{*}$ \\
Control & $1.52 \pm 0.06$ & $3.87 \pm 0.12$ & $12.5 \pm 1.23$ & $19.5 \pm 3.73$ \\
\hline
\end{tabular}

Data are presented as Mean $\pm \operatorname{SEM}(n=4)$. Values represent the glucose concentration $(\mu \mathrm{mol})$ in dialysate. Mean values marked with an asterisk $(*)$ were significantly different from those of respective control groups $(p<0.05)$ (derived from repeated-measures ANOVA and adjusted using Bonferroni correction).

dose did not increase as sharply as the control group. The glucose concentration was significantly lower than the $250,500 \mathrm{mg} / \mathrm{kg}$ treated group or the control group. Two of the above findings reinforces previous claims about $C$. asiatica having anti-hyperglycemic activity without inducing hypoglycemia $[8,9]$. Therefore, it might be devoid of one of the key flaws in many of the currently prescribed anti-diabetic medications [36].

To further ascertain, mechanism of anti-diabetic action, we measured the plasma insulin level of the test animals and found no significant increase in insulin secretion on C. asiatica administration, at all doses. This preliminary finding was further strengthened by a similar lack of activity shown by $C$. asiatica on isolated rat islets. Furthermore, liver glycogen content remained unaltered with respect to control group. Therefore, increased insulin secretion or increased sensitivity to insulin action can both be ruled out. It is to be noted that, wet mass of both liver and pancreas in control and treated groups did not significantly differ. Regeneration of pancreatic $\beta$-cell mass and enhanced glucose utilization can be preliminary ruled out [37].

An in situ intestinal perfusion of the GI tract shows marked reduction in glucose absorption. In $\mathrm{BaSO}_{4} \mathrm{GI}$ motility assay, intestinal motility was found to be significantly higher. Numerous published results have shown the ability of complex carbohydrate, high molecular weight, and viscous, soluble dietary fibers, to retard glucose absorption [38-40]. C. asiatica has been said to contain oligosaccharide centellose, resin and large amounts of insoluble dietary fibers [41]. Dietary fibers often provide a greater barrier to diffusion caused due to its high viscosity and ability to bind to glucose [38]. Dietary fibers are capable of significantly reducing the transit time in GI Tract of ingested food [42]. Reduced transit time can be translated as lesser time available for di-and polysaccharides in the meal to be digested and absorbed [43]. It logically follows a lower glucose peak concentration after the meal.

Six Segment test showed significantly higher amount of sucrose in stomach, upper, middle and lower intestine in C. asiatica administered groups. The latter three part of GI are most important for absorption of nutrients including sugars [44]. Disaccharides in its own form does not get absorbed due to lack to sucrose carriers, as carriers monosaccharides only are present in the GI tract [45]. Therefore, it is imperative that disaccharides get converted to monosaccharides first for absorption. Higher sucrose content in the GI Tract clearly reflects a reduced sucrose digestion throughout the GI Tract. This in turn, is shown by a significantly higher concentration of sucrose reaching the large intestine and caecum, which eventually remains unabsorbed and egested with faeces.

In the intestinal disaccharidase activity and the $\alpha$ amylase activity assay, $C$. asiatica was shown to have reduced the catabolism of sucrose and starch respectively. Since complex carbohydrates and disaccharides have first to be broken down into simpler monosaccharides [45], it follows that any inhibition of this catabolic process would retard sugar absorption, which would in turn, be shown as a lower glycemic peak. However, the precise mechanism of this inhibitory action remains to be studied.

In-vitro studies involving fiber binding assays clearly demonstrated glucose being bound by dietary fibers available in C. asiatica even at very low glucose concentrations. Glucose are carried by specific transport proteins [45].

Table 4 Glucose adsorption capacity of insoluble fibre of CA in different concentrations of glucose

\begin{tabular}{|c|c|c|c|c|c|}
\hline \multirow[t]{2}{*}{ Treatment } & \multicolumn{5}{|c|}{ Glucose bound $(\mathrm{mmol} / \mathrm{g})$} \\
\hline & $5 \mathrm{mmol} / \mathrm{l}$ & $10 \mathrm{mmol} / \mathrm{l}$ & $50 \mathrm{mmol} / \mathrm{l}$ & $100 \mathrm{mmol} / \mathrm{l}$ & $200 \mathrm{mmol} / \mathrm{l}$ \\
\hline CA $250 \mathrm{mg}$ & $0.03 \pm 0.01^{\mathrm{a}}$ & $0.91 \pm 0.11^{\mathrm{a}}$ & $4.88 \pm 0.93^{\mathrm{a}}$ & $9.23 \pm 1.02^{a}$ & $19.43 \pm 3.37^{\mathrm{a}}$ \\
\hline CA $500 \mathrm{mg}$ & $0.06 \pm 0.01^{b}$ & $1.87 \pm 0.43^{b}$ & $6.78 \pm 2.10^{b}$ & $13.89 \pm 3.67^{b}$ & $23.88 \pm 4.87^{b}$ \\
\hline CA $1000 \mathrm{mg}$ & $0.08 \pm 0.02^{c}$ & $2.67 \pm 0.61^{c}$ & $8.93 \pm 1.98^{c}$ & $16.75 \pm 4.12^{c}$ & $29.94 \pm 7.50^{c}$ \\
\hline CMC $1000 \mathrm{mg}$ & $0.08 \pm 0.01^{c}$ & $2.71 \pm 0.45^{c}$ & $9.32 \pm 2.09^{c}$ & $17.81 \pm 3.78^{c}$ & $30.97 \pm 6.88^{c}$ \\
\hline
\end{tabular}

Data are presented as Mean \pm SEM $(n=4)$. Data represent the millimoles of glucose bound by each gram of the CA extract at different glucose concentrations $(5-200 \mathrm{mmol} / \mathrm{l})$. Glucose bound $=$ (glucose concentration of original solution - glucose concentration when the adsorption reached equilibrium) $\times$ volume of solution $\div$ weight of dietary fibre. Mean values in the same column marked with different letters $\left({ }^{a},{ }^{b}\right.$, and ${ }^{c}$ ) were significantly different at $p<0.05$ (Values which were found to be statistically similar to the positive control were denoted as "c"; they present strong fibre binding. Values denoted by "a" and "b" were statistically different from both the positive control and themselves; these values represent non significant fibre binding) (derived from repeated-measures ANOVA and adjusted using Bonferroni correction). 
Bound glucose is probably incapable of fitting the active site of these transport proteins. This fully validates our initial findings in the gut perfusion experiments, which too showed a hindrance in glucose absorption. This now can be fully attributed to glucose-fiber binding in Centella asiatica whole plant powder.

Further research is underway, in our labs, for identifying the active molecules responsible for inhibiting $\alpha$ amylase and disaccharidase. We also intend to study the protein transporters, most affected by the active compound, via radio-ligand binding assay. In conclusion, we report absence of enhanced insulin secretion in $C$. asiatica treated animal groups. No significant improvement was seen in liver glycogen deposition either. Findings in previous studies reporting anti-hyperglycemic activity in C. asiatica, can be probably attributed to reduced carbohydrate breakdown, glucose-fiber binding, thus, and overall reduced glucose absorption through the GI tract. Furthermore, on chronic intake, it has ability to lower harmful LDL and Cholesterol in animal models while elevating the beneficial HDL. C. asiatica calls for further attention from the scientific community to further elucidate its activity and establish its safety profile.

\section{Conclusions}

Our studies confirm the previous findings showing antihyperglycemic action of $C$. Asiatica. Additionally, we have elucidated that $C$. Asiatica is capable of inhibiting absorption of glucose both by inhibition of intestinal disaccharidase enzymes and $\alpha$-amylase and by glucosefibre binding. On chronic intake, it has lowers serum LDL and Cholesterol and elevates the HDL. Therefore, its traditional use, as mentioned above is justified and calls for further research, to optimize its anti-diabetic activity.

\section{Competing interests}

This study was funded by a "Graduate Research Grant" of North South University.

\section{Authors' contributions}

AUK: Conducted experiments, carried out Data Analysis, revised the preliminary manuscript. MBS: Designed and established in-vitro protocols, conducted experiments, wrote the manuscript. NMD'C: Carried out experiments, wrote the manuscript, and revised the manuscript. FA: Carried out the in-vitro tests and phytochemical analysis. She was also responsible for preparation of the extract. AA: Carried out the initial screening tests and toxicological studies on the used extract. He was responsible for preparation of the extract. JMAH: Provided overall supervision and coordinated all experimental activities, initially approved the experimental protocols, revised manuscript, carried out experiments. All authors read and approved the final manuscript.

\section{Acknowledgement}

The authors would like to extend their heartfelt gratitude to Mrs. Junaida Khaleque, Khorrul Jannat Jelly, and Muhammad Rajib Jahan for their valuable advice and technical support.

Received: 10 August 2013 Accepted: 15 January 2014

Published: 18 January 2014

\section{References}

1. Wild S, Roglic G, Green A, Sicree R, King H: Global prevalence of diabetes estimates for the year 2000 and projections for 2030. Diabetes Care 2004, 27(5):1047-1053.

2. Jaber LA, Halapy H, Fernet M, Tummalapalli S, Diwakaran H: Evaluation of a pharmaceutical care model on diabetes management. Ann Pharmacother 1996, 30(3):238-243.

3. Clement S: Diabetes self-management education. Diabetes Care 1995, 18(8):1204-1214

4. Peyrot M, Rubin RR, Lauritzen T, Snoek FJ, Matthews DR, Skovlund SE: Psychosocial problems and barriers to improved diabetes management: results of the Cross-National Diabetes Attitudes, Wishes and Needs (DAWN) Study. Diabet Med 2005, 22(10):1379-1385.

5. Bailey CJ, Day C: Traditional plant medicines as treatments for diabetes. Diabetes Care 1989, 12(8):553-564.

6. Alam M, Siddiqui M, Husain W: Treatment of diabetes through herbal drugs in rural India. Fitoterapia 1990, 61(3):240-242.

7. Ernst E, Pittler MH, Stevinson C, White A: The desktop guide to complementary and alternative medicine: an evidence-based approach. Mosby International Ltd; 2001.

8. Mutayabarwa C, Sayi J, Dande M: Hypoglycaemic activity of Centella asiatica (L) Urb. East and central African Journal of Pharmaceutical Sciences 2005, 6(2):30-35.

9. Gayathri V, Lekshmi P, Padmanabhan R: Anti-diabetes activity of ethanol extract of Centella asiatica (L.) Urban (whole plant) in Streptozotocininduced diabetic rats, isolation of an active fraction and toxicity evaluation of the extract. International Journal of Medicinal and Aromatic Plants 2011, 1(3):278-286.

10. Chauhan P, Pandey I, Dhatwalia VK: Evaluation of the anti-diabetic effect of ethanolic and methanolic extracts of Centella asiatica leaves extract on alloxan induced diabetic rats. Adv Biol Res 2010, 4:27-30.

11. Bayne K: Revised Guide for the Care and Use of Laboratory Animals available. American Physiological Society. Physiologist 1996, 39(4):199-208.

12. Lenzen S: The mechanisms of alloxan-and streptozotocin-induced diabetes. Diabetologia 2008, 51(2):216-226.

13. Trinder P: Enzymatic Colorimetric method for estimation of Glucose Test (GOD-PAP method), uric acid and phosohlipids. Ann Clin Biochem 1969, 6:25.

14. Moskalewski S: Studies on the culture and transplantation of isolated islets of langerhans of the guinea pig. Proceedings of the Koninklijke Nederlandse Akademie van Wetenschappen Series C Biological and Medical Sciences 1969, 72(2):157.

15. Chau C-F, Huang $Y-L$, Lee $M-H$ : In vitro hypoglycemic effects of different insoluble fiber-rich fractions prepared from the peel of Citrus sinensis $\mathrm{L}$. cv. Liucheng. J Agric Food Chem 2003, 51(22):6623-6626.

16. Van der Vies J: Two methods for the determination of glycogen in liver. Biochem J 1954, 57(3):410.

17. Swintosky J, Pogonowska-Wala E: The in-situ rat gut technique. Pharmacy Int 1982, 3:163-167.

18. Hannan J, Ali L, Rokeya B, Khaleque J, Akhter M, Flatt P, Abdel-Wahab Y: Soluble dietary fibre fraction of Trigonella foenum-graecum (fenugreek) seed improves glucose homeostasis in animal models of type 1 and type 2 diabetes by delaying carbohydrate digestion and absorption, and enhancing insulin action. Br J Nutr 2007, 97(03):514-521.

19. Goto Y, Yamada K, Ohyama T, Matsuo T, Odaka H, Ikeda H: An aglucosidase inhibitor, $\mathrm{AO}-128$, retards carbohydrate absorption in rats and humans. Diabetes Res Clin Pract 1995, 28(2):81-87.

20. Chatterjee T: Handbook of laboratory Mice and Rats. India: Jadavpur University; 1993:133-139.

21. Ou S, Kwok K-C, Li Y, Fu L: In vitro study of possible role of dietary fiber in lowering postprandial serum glucose. J Agric Food Chem 2001, 49(2):1026-1029.

22. Shukla A, Rasik A, Jain G, Shankar R, Kulshrestha D, Dhawan B: In vitro and in vivo wound healing activity of asiaticoside isolated from Centella asiatica. J Ethnopharmacol 1999, 65(1):1-11.

23. Brownlee $\mathrm{M}$ : The pathobiology of diabetic complications a unifying mechanism. Diabetes 2005, 54(6):1615-1625.

24. Turner R, Holman R, Cull C, Stratton I, Matthews D, Frighi V, Manley S, Neil A, Mcelroy K, Wright D: Intensive blood-glucose control with sulphonylureas or insulin compared with conventional treatment and 
risk of complications in patients with type 2 diabetes (UKPDS 33). Lancet 1998, 352(9131):837-853.

25. Heilig C, Concepcion L, Riser B, Freytag S, Zhu M, Cortes P: Overexpression of glucose transporters in rat mesangial cells cultured in a normal glucose milieu mimics the diabetic phenotype. J Clin Investig 1995, 96(4):1802.

26. Kaiser N, Sasson S, Feener EP, Boukobza-Vardi N, Higashi S, Moller DE, Davidheiser S, Przybylski RJ, King GL: Differential regulation of glucose transport and transporters by glucose in vascular endothelial and smooth muscle cells. Diabetes 1993, 42(1):80-89.

27. Haller H: Postprandial glucose and vascular disease. Diabet Med 1997, 14(S3):S50-S56.

28. Koya D, King GL: Protein kinase C activation and the development of diabetic complications. Diabetes 1998, 47(6):859-866.

29. Ceriello A, Taboga C, Tonutti L, Giacomello R, Stel L, Motz E, Pirisi M: Postmeal coagulation activation in diabetes mellitus: the effect of acarbose. Diabetologia 1996, 39(4):469-473.

30. Thornalley PJ: Advanced glycation and the development of diabetic complications. Unifying the involvement of glucose, methylglyoxal and oxidative stress. Endocrinology And Metabolism-London- 1996, 3:149-166.

31. Krentz AJ, Bailey CJ: Oral antidiabetic agents. Drugs 2005, 65(3):385-411.

32. Gadi R, Samaha FF: Dyslipidemia in type 2 diabetes mellitus. Current diabetes reports 2007, 7(3):228-234.

33. Group UPDS: Tight blood pressure control and risk of macrovascular and microvascular complications in type 2 diabetes: UKPDS 38. BMJ 1998, 317(7160):703-713

34. Hall JE: Guyton and Hall Textbook of Medical Physiology: Enhanced E-book. 11th edition. Philadelphia, Pennsylvania: Elsevier Health Sciences; 2010:974.

35. Wilson PW, Cupples LA, Kannel WB: Is hyperglycemia associated with cardiovascular disease? The Framingham Study. Am Heart J 1991, 121(2):586-590.

36. Bodmer M, Meier C, Krähenbühl S, Jick SS, Meier CR: Metformin, Sulfonylureas, or Other Antidiabetes Drugs and the Risk of Lactic Acidosis or Hypoglycemia A nested case-control analysis. Diabetes Care 2008, 31(11):2086-2091.

37. Ashmore J, Hastings AB, Nesbett FB: The effect of diabetes and fasting on liver glucose-6-phosphatase. Proc Natl Acad Sci USA 1954, 40(8):673.

38. Jenkins D, Wolever T, Leeds AR, Gassull MA, Haisman P, Dilawari J, Goff DV, Metz GL, Alberti K: Dietary fibres, fibre analogues, and glucose tolerance: importance of viscosity. Br Med J 1978, 1(6124):1392.

39. Groop P-H, Aro A, Stenman S, Groop L: Long-term effects of guar gum in subjects with non-insulin-dependent diabetes mellitus. Am J Clin Nutr 1993, 58(4):513-518.

40. Edwards C, Johnson I, Read N: Do viscous polysaccharides slow absorption by inhibiting diffusion or convection? Eur J Clin Nutr 1988, 42(4):307.

41. Jamil SS, Nizami Q, Salam M: Centella asiatica (Linn.) Urban: a review. Natural Product Radiance 2007, 6(2):158-170.

42. Burkitt D, Walker A, Painter NS: Effect of dietary fibre on stools and transittimes, and its role in the causation of disease. Lancet 1972, 300(7792): 1408-1411.

43. Holgate A, Read N: Relationship between small bowel transit time and absorption of a solid meal influence of metoclopramide, magnesium sulfate, and lactulose. Dig Dis Sci 1983, 28:812-819.

44. Reynell P, Spray G: The simultaneous measurement of absorption and transit in the gastro-intestinal tract of the rat. J Physiol 1956, 131(2):452-462

45. Crane RK: The physiology of the intestinal absorption of sugars. Physiological effects of food carbohydrates 1975, 15(1):1-19.

doi:10.1186/1472-6882-14-31

Cite this article as: Kabir et al: Anti-hyperglycemic activity of Centella asiatica is partly mediated by carbohydrase inhibition and glucose-fiber binding. BMC Complementary and Alternative Medicine 2014 14:31.

\section{Submit your next manuscript to BioMed Central and take full advantage of:}

- Convenient online submission

- Thorough peer review

- No space constraints or color figure charges

- Immediate publication on acceptance

- Inclusion in PubMed, CAS, Scopus and Google Scholar

- Research which is freely available for redistribution 